\title{
Natural Hazard Management from a Coevolutionary Perspective: Exposure and Policy Response in the European Alps
}

\author{
Sven Fuchs, Veronika Röthlisberger, Thomas Thaler, Andreas Zischg \& \\ Margreth Keiler
}

To cite this article: Sven Fuchs, Veronika Röthlisberger, Thomas Thaler, Andreas Zischg \& Margreth Keiler (2017) Natural Hazard Management from a Coevolutionary Perspective: Exposure and Policy Response in the European Alps, Annals of the American Association of Geographers, 107:2, 382-392, DOI: 10.1080/24694452.2016.1235494

To link to this article: http://dx.doi.org/10.1080/24694452.2016.1235494
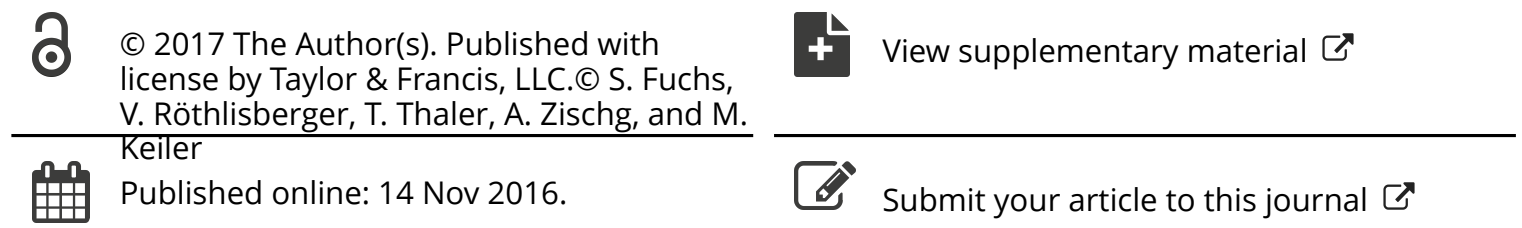

Џll Article views: 348

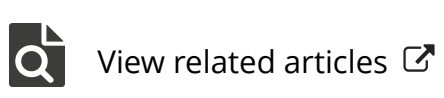

View Crossmark data 〔 


\title{
Natural Hazard Management from a Coevolutionary Perspective: Exposure and Policy Response in the European Alps
}

\author{
Sven Fuchs (10,* Veronika Röthlisberger (1), ${ }^{\dagger}$ Thomas Thaler (1),* Andreas Zischg (1), ${ }^{\dagger}$ and \\ Margreth Keiler $\mathbb{1}^{\ddagger}$
}

\author{
*Institute for Mountain Risk Engineering, University of Natural Resources and Life Sciences \\ ${ }^{\dagger}$ Mobiliar Lab for Natural Risks, Oeschger Centre for Climate Change Research, and Institute of Geography, University of Bern \\ ${ }^{\ddagger}$ Institute of Geography, University of Bern
}

\begin{abstract}
A coevolutionary perspective is adopted to understand the dynamics of exposure to mountain hazards in the European Alps. A spatially explicit, object-based temporal assessment of elements at risk to mountain hazards (river floods, torrential floods, and debris flows) in Austria and Switzerland is presented for the period from 1919 to 2012. The assessment is based on two different data sets: (1) hazard information adhering to legally binding land use planning restrictions and (2) information on building types combined from different nationallevel spatial data. We discuss these transdisciplinary dynamics and focus on economic, social, and institutional interdependencies and interactions between human and physical systems. Exposure changes in response to multiple drivers, including population growth and land use conflicts. The results show that whereas some regional assets are associated with a strong increase in exposure to hazards, others are characterized by a below-average level of exposure. The spatiotemporal results indicate relatively stable hot spots in the European Alps. These results coincide with the topography of the countries and with the respective range of economic activities and political settings. Furthermore, the differences between management approaches as a result of multiple institutional settings are discussed. A coevolutionary framework widens the explanatory power of multiple drivers to changes in exposure and risk and supports a shift from structural, security-based policies toward an integrated, risk-based natural hazard management system. Key Words: coevolution, European Alps, exposure, natural hazard management, path dependency.
\end{abstract}

本文採用共同演化的观点来理解欧洲阿尔卑斯地区暴露于山区灾害的动态。本文呈现奥地利和瑞士在 1919 年至 2012 年间, 对山区灾害 (洪泛、山洪暴发与泥石流) 而言具有风险元素之特定空间且基于对象的 时间评估。该评估是根据下列两组不同的数据集: (1) 遵循具法律约束力的土地使用规划限制之灾害信息, 以及 (2) 从不同的国家层级空间数据组合而成的建筑形态信息。我们探讨这些跨领域动态, 并聚焦经 济、社会与制度间的相互依赖, 以及人类和物理系统的互动。曝险度在回应包括人口成长及土地使用冲 突等多重驱力时有所改变。研究结果显示, 当若干区域资产与灾害曝险度的显着增加有关时, 其他区域 则以低于平均的曝险度为特徵。空间与时间的结果, 显示出欧洲阿尔卑斯地区热点的相对稳定性。这些 研究与各国家的地志学, 以及各别的经济活动范围与政治环境相符。此外, 本文探讨因多重制度环境所 导致的管理方法差异。共同演化架构, 扩张了多重驱力之于曝险度和风险的改变的解释力, 并支持从结 构性、以安全为基础的政策转变为整合性的、以风险为基础的自然灾害管理系统。关键词：共同演化, 欧洲阿尔卑斯地区，曝险，自然灾害管理, 路径依赖。

\begin{abstract}
Se adopta una perspectiva co-evolucionista para entender la dinámica de la exposición a los riesgos de montaña en los Alpes europeos. Se presenta una evaluación temporal espacialmente explícita y basada en objeto de los elementos de riesgo en catástrofes de montaña (inundaciones fluviales, inundaciones torrenciales y flujos de detritos) en Austria y Suiza, para el período de 1919 a 2012. La evaluación descansa en dos conjuntos de datos diferentes: (1) información de riesgos que adhiere a las restricciones de planificación de uso del suelo legalmente obligatorias, y (2) información combinada sobre tipos de construcciones desde diferentes fuentes de datos espaciales a nivel nacional. Discutimos estas dinámicas transdisciplinarias y nos enfocamos en interdependencias e interacciones económicas, sociales e institucionales entre sistemas humanos y físicos. La exposición
\end{abstract}

(C) S. Fuchs, V. Röthlisberger, T. Thaler, A. Zischg, and M. Keiler

This is an Open Access article. Non-commercial re-use, distribution, and reproduction in any medium, provided the original work is properly attributed, cited, and is not altered, transformed, or built upon in any way, is permitted. The moral rights of the named authors have been asserted.

Annals of the American Association of Geographers, 107(2) 2017, pp. 382-392 Published with license by Taylor \& Francis, LLC. 
cambia en respuesta a múltiples controles, incluyendo crecimiento de la población y conflictos por usos del suelo. Los resultados muestran que mientras algunas ventajas regionales están asociadas con un fuerte incremento en exposición a los riesgos, otras están caracterizadas por un nivel de exposición por debajo del promedio. Los resultados espaciotemporales indican puntos calientes relativamente estables en los Alpes europeos. Estos resultados coinciden con la topografía de los países y con el respectivo ámbito de actividades económicas y el contexto político. Adicionalmente, se discuten las diferencias entre los enfoques de administración como resultado de múltiples escenarios institucionales. Un marco co-evolucionario amplía el poder explicativo de múltiples controles a los cambios en exposición y riesgo, y soporta un cambio de políticas estructurales, basadas en seguridad, hacia un sistema integrado de manejo de catástrofes naturales basado en riesgo. Palabras clave: coevolución, Alpes europeos, exposición, manejo de catástrofes naturales, dependencia en la ruta.

$\mathrm{I}$ n Europe, approximately 40 percent of the total land area is mountainous and is home to almost 20 percent of the total population (Nordregio 2004). Consequently, mountain regions are characterized by a significant number of settlements and economic and recreational areas. Only about 17 percent of the European Alps is suitable for permanent settlement due to topographic constraints, however (Tappeiner, Borsdorf, and Tasser 2008). As a result, mountain region developments are inherently linked to natural hazard risk, as land development occurs in hazard-prone areas where many settlements are located on alluvial fans and in floodplains. Flood risk management differs remarkably between floodplains along large rivers (e.g., the Rhine in Europe or the Mississippi in the United States) and the floodplains of alpine rivers. Whereas large rivers are predominantly managed with flood retention and levee constructions (Remo, Carlson, and Pinter 2012; Theiling and Burant 2013), mountainous areas are primarily managed by restricting the development of settlements in floodplains. Consequently, spatiotemporal exposure and the vulnerability of elements at risk plays a dominant role in risk management.

The main drivers of natural hazard risk are high reliefs, hydroclimatology, and the effects of climate dynamics on hydrological hazards (Keiler, Knight, and Harrison 2010). Hydrological hazards constitute a major threat to communities and assets, even though they occur episodically (Fuchs et al. 2013), especially if exposure and vulnerability are not properly managed (Zimmermann and Keiler 2015). These two aspects have only received scientific attention relatively recently (Papathoma-Köhle et al. 2011; Totschnig and Fuchs 2013; Fuchs, Keiler, and Zischg 2015; Papathoma-Köhle et al. 2015), whereas the overall concept of risk that combines hazard, exposure, and vulnerability had already been introduced in operational risk management for decades (Keiler et al. 2004; Kienholz et al. 2004).
Despite the considerable efforts to reduce mountain hazard risk, particularly with the implementation of technical means such as levees and retention basins (Holub and Fuchs 2009), the losses due to hydrological hazards in Europe remain significant (Andres, Badoux, and Hegg 2015; Fuchs, Keiler, and Zischg 2015). Although there is some evidence of increasing losses, which can be found in the publications of large reinsurers (Munich Re 2016; Swiss Re 2016), some scholars stated that underlying trends should be carefully interpreted. Mudelsee et al. (2003) analyzed flood magnitudes and concluded that there is no evidence of recent upward trends describing the occurrence of large flood events in central Europe. Similarly, Barredo (2009) reported no clear positive trend in flood losses in Europe once the losses are normalized by socioeconomic development indicators. Furthermore, when flood data in the United States are presented in terms of damage per unit wealth, a slight and statistically insignificant downward trend is observed (Loucks and Stedinger 2007).

Besides hazard dynamics (i.e., changes in the natural frequency and magnitude of events due to climatic change), shifts in hazard losses could result from (1) changing exposure of elements at risk due to overall population migration and associated land development, (2) changing vulnerability due to the presence or absence of technical mitigation measures, and (3) a greater awareness of threats considered in land use planning. In the past, spatially explicit data on elements at risk in Europe were fragmentary; a spatiotemporal assessment of exposure was limited to studies using large-scale, aggregated data (Keiler 2004; Keiler et al. 2006; Fuchs et al. 2013) and neglected any small-scale but supraregional dynamics. Spatially inclusive and comprehensive analyses on national levels were undertaken, for example, on flood risk in The Netherlands (Jongman et al. 2014) and on mountain hazards in Austria (Fuchs, Keiler, and Zischg 2015) when such 
data became recently available. In the following review, we focus on residential buildings (RBs) exposed to flood hazards in The European Alps, and we show how such data can be used to improve our understanding of hazard exposure and how a coevolutionary framework widens the explanatory power of multiple drivers in exposure dynamics. The coevolutionary framework provides a guideline for analyzing and explaining the linkage between exposure and policy.

\section{Assessing Coevolution in Natural Hazard Management}

We attempt to address challenges attributed to institutional changes in natural hazard management by focusing on the exposure of RBs in the European Alps from a coevolutionary perspective. Coevolution includes two or more interdependently evolving systems (Gual and Norgaard 2010). The aim is to analyze and understand the coevolutionary changes within the different interacting systems, where coevolutionary dynamics are path dependent (Kallis 2007). These dynamics include social adaptation to environmental change. A central theme inherent to coevolutionary thinking in social science is the analysis of institutional changes, especially with respect to the development of human behavior. Institutions are defined as a constant (formally legal and informally social) norm over a certain period of time (van den Bergh and Stagl 2003). Institutions are responsible for the organization of structures to optimize for social and economic behaviors (e.g., by minimizing uncertainty). Therefore, institutions have a direct influence on individuals and vice versa. Institutions influence the behavior of individuals (top down); their behavior and habitat are also key drivers for the development of new institutions or institutional changes (bottom up; Hodgson 2006). In summary, institutions define rules or procedures that support decision-making processes.

The aim is to interpret and to holistically explain exposure evolution in the European Alps with respect to policy responses and technological developments. The insights then support the valuation of natural hazard management policies. We identified two evolutionary systems:

- The first system is characterized by population pressures (i.e., demand for increased residences in hazard areas) associated with different behaviors, norms, beliefs, and physical attributes. Over time, the behavior and attributes of the populations in
Austria and Switzerland changed. This is exemplified by the increase of single households compared to multihouseholds starting in the 1960 s or gradually more numerous requests for secondary residences over the last 100 years (Statistik Austria 2004). Changes were based on socioeconomic developments within the society and external drivers (e.g., influx of homeowners from abroad). Furthermore, societal attributes change (e.g., new designs and uses for RBs, the number of inhabitants from 16.57 people per RB in 1919 to 4.59 people in 2012).

- The second evolutionary system involves changes in natural hazard management policy. For decades since the 1890s, the focus was on the implementation of structural engineering measures (Holub and Fuchs 2009). From the 1970s onward, nonstructural measures (e.g., land use planning) supplemented these engineered structures. Over time, however, key strategies in natural hazard management were incapable of sufficiently addressing the magnitude of associated losses. Institutions and respective policymakers currently rely on a combination of structural and nonstructural measures to reduce natural hazard risk in the European Alps (Fuchs 2009) and beyond (Kubal et al. 2009). There is an evident shift in natural hazard discourse away from exclusively engineered solutions toward broader integrated management strategies. These include land use management and other incentives to discourage developments in high-risk areas (Fuchs 2009). Consequently, this shift has been identified as a key point of contention in policy discussions, especially toward the implementation of nonstructural measures (Wiering and Immink 2006). This was triggered by crises such as the Galtür avalanche event in 1999 (Keiler 2004) and flood events in 2002 and 2005 (Bard, Renard, and Lang 2012). These catastrophic events provide new opportunities for actors from all administrative levels to introduce new management systems. Despite these shifts, natural hazard management still predominantly considers the use of structural measures (Thaler, Priest, and Fuchs 2016). Additionally, the implementation of structural mitigation measures has encouraged increases in the number of buildings in hazard areas.

\section{Assessing Flood Hazard Exposure}

Two different data sets were used for this study. Information on flood hazards provided input for 
the exposure assessment, in addition to data on building inventory in Austria and Switzerland (see Figure 1). Hazards such as river and torrential flooding (i.e., dynamic flooding with sediment transport and debris flows) in mountain rivers were assessed.

Available hazard maps were combined with nation-wide flood modeling results (see supplementary materials) to obtain spatial information on flood hazards. We defined a low- to medium-probability event as a source for the exposure assessment, in accordance with the requirements of the European Union Floods Directive (Commission of the European Communities 2007).

For the building exposure assessment, information on RBs was computed according to Fuchs, Keiler, and Zischg (2015), using specified information related to the entire building inventory. This information is available in a governmental database and contains details about the location and size of each building, the building category, and the year and period of construction (Bundesamt für Statistik 2012; Statistik Austria 2012).

Exposed buildings are defined as built structures that are susceptible to hydrological hazards. The hazard information was overlaid with building inventory data in a geographic information system. Each building was characterized by its main use, which was assessed by the net area of used space allotted for the different purposes of each floor.

\section{Results}

\section{Analysis of Exposure Evolution}

An overview on the number of RBs is provided in Table 1. A total of 3,574,198 RBs is located in Austria and Switzerland, of which 14.14 percent are exposed to hydrological hazards. The percentage exposed is slightly higher in Switzerland than in Austria. Almost two thirds (62.6 percent) of these buildings are singlefamily houses (SFHs), and slightly more than one third (37.4 percent) are apartment buildings (ABs). Between 1919 and 2012, the overall share of exposed RBs dropped around 2 percent, whereas the absolute number increased by a factor of 5 . Similarly, the overall share of exposed SFHs dropped by around 2 percent, but the overall number of exposed SFHs increased by a factor of 5.6. Finally, the overall share of exposed $A B s$ dropped by around 1.5 percent, but the overall number of exposed ABs increased by a factor of 4.2. In Switzerland, the exposure is generally slightly higher than in Austria.

The temporal development of the total RB stock is shown in Figure 2. Starting with an almost similar number of RBs in 1919 (Austria, 312,962; Switzerland, $307,751)$, the increase until 2012 was considerably higher in Austria $(1,984,475)$ than in Switzerland $(1,589,723)$. This increase followed a similar shape until 1960; thereafter, the increase was steeper in Austria than in Switzerland. A comparable pattern is observed for SFHs, starting

\section{Residential buildings exposed to floods}

\section{Community level}

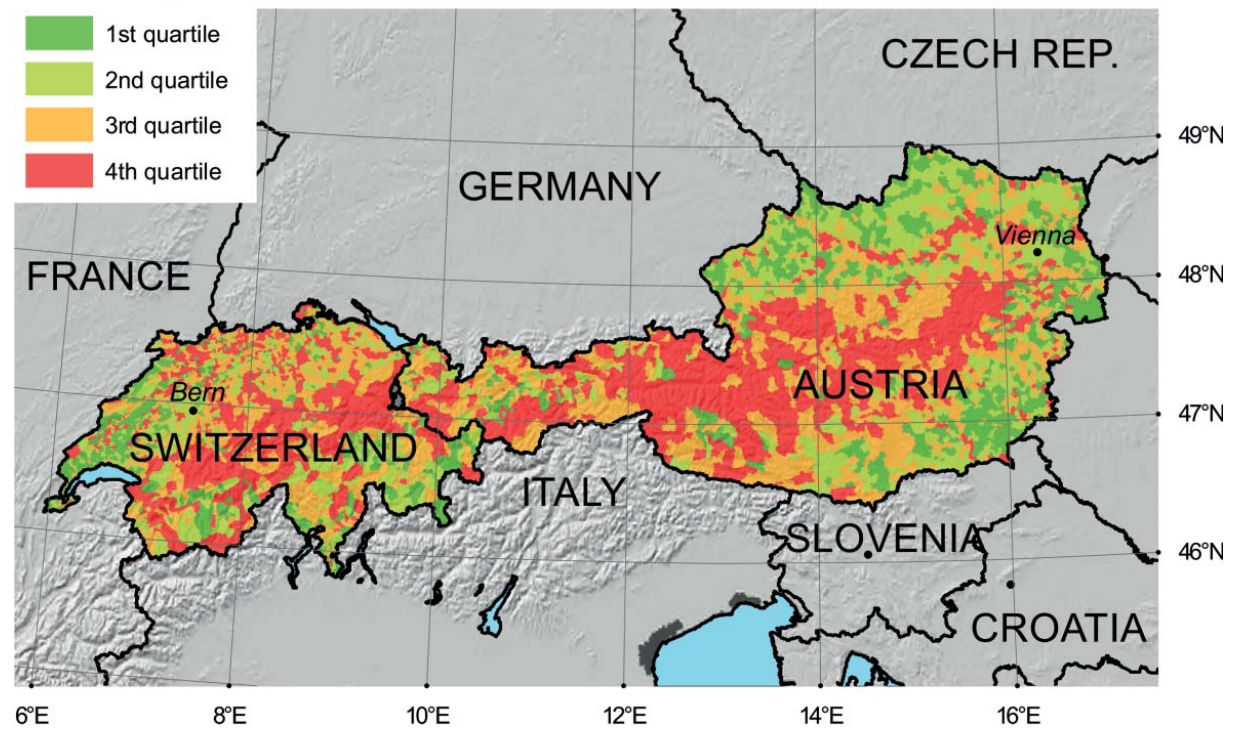

Figure 1. Exposure rate of residential buildings to hydrological hazards in Austria and Switzerland (exposed buildings to all buildings within a local authority, shown in terms of quartiles). (Color figure available online.) 


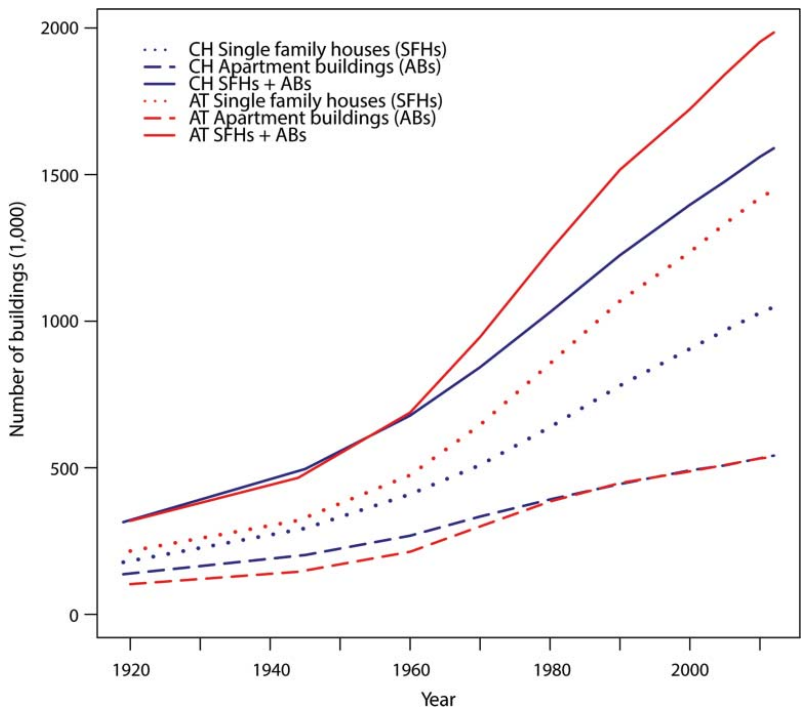

Figure 2. Absolute number of residential buildings in Austria and Switzerland (total number, single-family houses and apartment buildings) between 1919 and 2012. $\mathrm{CH}=$ Switzerland; AT = Austria; $\mathrm{SFH}=$ single-family house; $\mathrm{AB}=$ apartment building. (Color figure available online.)

from a total of 211,586 (Austria) and 173,309 (Switzerland), with a steeper increase in Austria than in Switzerland after 1960 and reaching totals of 1,447,144 (Austria) and 1,048,217 (Switzerland). In contrast, in 1919, there was a higher number of ABs in Switzerland $(134,442)$ than in Austria $(101,376)$. This number increased to almost the same amount for both countries (537,331 in Austria and 541,506 in Switzerland) in 2012.

Starting in 1919, there was a lower number of exposed RBs in Austria $(42,219)$ than in Switzerland $(58,446)$. These numbers increased until 2012, where the total numbers were higher in Austria $(267,759)$ than in Switzerland $(237,454)$. Similarly, the number of exposed SFHs increased from 26,473 (Austria) and
29,371 (Switzerland) to 179,257 (Austria) and 137,129 (Switzerland) between 1919 and 2012. In 1919 , the number of exposed ABs started as a moderate amount in both countries (15,746 in Austria and 29,075 in Switzerland), which increased to 88,502 (Austria) and 100,325 (Switzerland) in 2012 (see Table 1).

Spatial analysis of the data reveals that hydrological hazards are an evident threat to municipalities, even if considerable differences between regions exist (Figure 1). In general, the exposure to hydrological hazards is defined as the share of exposed RBs to all existing RBs within a municipality. Exposure is low (first quartile) in communities located in the northern and southern alpine foreland and high (fourth quartile) in municipalities located in the high mountain areas around the main divide. The large river courses (Rhone, Aare, Rhine, Danube, and Mur) coincide with the higher levels of exposure in municipalities situated along these features. Moreover, some regions in the Central Alps are associated with low exposure values, even though there are above-average numbers of hazard events (Fuchs, Keiler, and Zischg 2015). This observation can be partially explained by a rigorous regional spatial planning policy (Thaler 2014; Thaler, Priest, and Fuchs 2016) and is discussed in the following section.

The temporal analysis reveals distinct differences between the Eastern and Western Alps. As shown in Figure 3, the share of exposed SFHs (number and value) compared to the entire number of SFHs decreased from 16.95 percent to 13.08 percent in Switzerland but was more or less constant in Austria (from 12.51 percent in 1919 to 12.39 percent in 2012). Hence, although the absolute number of exposed SFHs is higher in Austria than in Switzerland (Table 1), the relative distribution is reversed. The

Table 1. Overview of residential buildings in Austria and Switzerland

\begin{tabular}{|c|c|c|c|c|c|c|c|c|c|}
\hline & \multirow{2}{*}{$\begin{array}{c}\text { Total RB } \\
\quad N\end{array}$} & \multicolumn{2}{|c|}{ Total RB exposed } & \multirow{2}{*}{$\begin{array}{c}\text { Total SFH } \\
N\end{array}$} & \multicolumn{2}{|c|}{ Total SFH exposed } & \multirow{2}{*}{$\begin{array}{c}\text { Total AB } \\
\quad N\end{array}$} & \multicolumn{2}{|c|}{ Total AB exposed } \\
\hline & & N & $\%$ & & $N$ & $\%$ & & $N$ & $\%$ \\
\hline CH 1919 & 307,751 & 58,446 & 18.99 & 173,309 & 29,371 & 16.95 & 134,442 & 29,075 & 21.63 \\
\hline CH 2012 & $1,589,723$ & 237,454 & 14.94 & $1,048,217$ & 137,129 & 13.08 & 541,506 & 100,325 & 18.53 \\
\hline AT 1919 & 312,962 & 42,219 & 13.49 & 211,586 & 26,473 & 12.51 & 101,376 & 15,746 & 15.53 \\
\hline AT 2012 & $1,984,475$ & 267,759 & 13.49 & $1,447,144$ & 179,257 & 12.39 & 537,331 & 88,502 & 16.47 \\
\hline $\mathrm{CH}+\mathrm{AT} 1919$ & 620,713 & 100,665 & 16.22 & 384,895 & 55,844 & 14.51 & 235,818 & 44,821 & 19.01 \\
\hline CH + AT 2012 & $3,574,198$ & 505,213 & 14.14 & $2,495,361$ & 316,386 & 12.68 & $1,078,837$ & 188,827 & 17.50 \\
\hline
\end{tabular}

Note. $\mathrm{RB}=$ residential buildings; $\mathrm{SFH}=$ single-family house; $\mathrm{AB}=$ apartment building; $\mathrm{CH}=$ Switzerland; $\mathrm{AT}=$ Austria. 

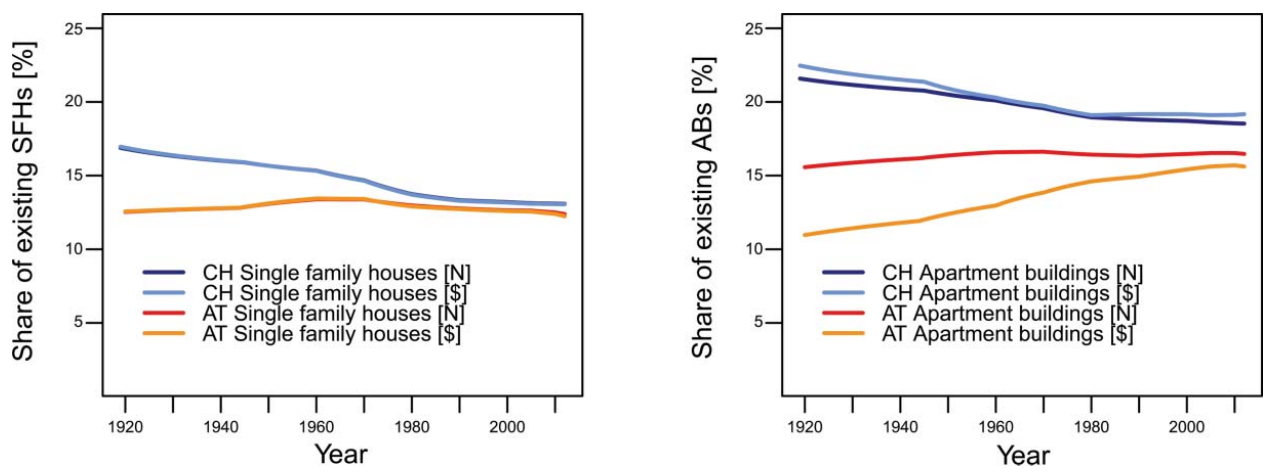

Figure 3. Share of exposed single-family houses (left) and apartment buildings (right) in Austria and Switzerland, relative to the total number of SFHs and ABs per country. The share of existing SFHs (left) is essentially identical in number and value for both Austria and Switzerland. This effect gives the appearance of only two graph lines when in fact there are four. $\mathrm{CH}=$ Switzerland; $\mathrm{AT}=\mathrm{Austria}$; SFH $=$ single-family house; $A B=$ apartment building. (Color figure available online.)

temporal $\mathrm{ABs}$ pattern is comparable to the one for SFHs and shows a slight decrease in the number of exposed ABs from 21.63 percent to 18.53 percent in Switzerland, with a similar progression for the values exposed. The Austrian data, in contrast, show a slightly increasing trend for the relationship between exposed $\mathrm{ABs}$ and the total $\mathrm{ABs}$ (from 15.53 percent in 1919 to 16.47 percent in 2012; the highest value is 16.62 percent in 1970) and a strong increase in the values. Hence, even if the increase in exposed buildings for the 1919 to 2012 period is lower in Switzerland than in Austria (factor of 4.67 vs. 6.77 for SFHs, 3.45 vs. 5.62 for $A B s$ ), the relative share of exposed SFHs and ABs remains higher in Switzerland than in Austria over 1919 to 2012. If the entire population is

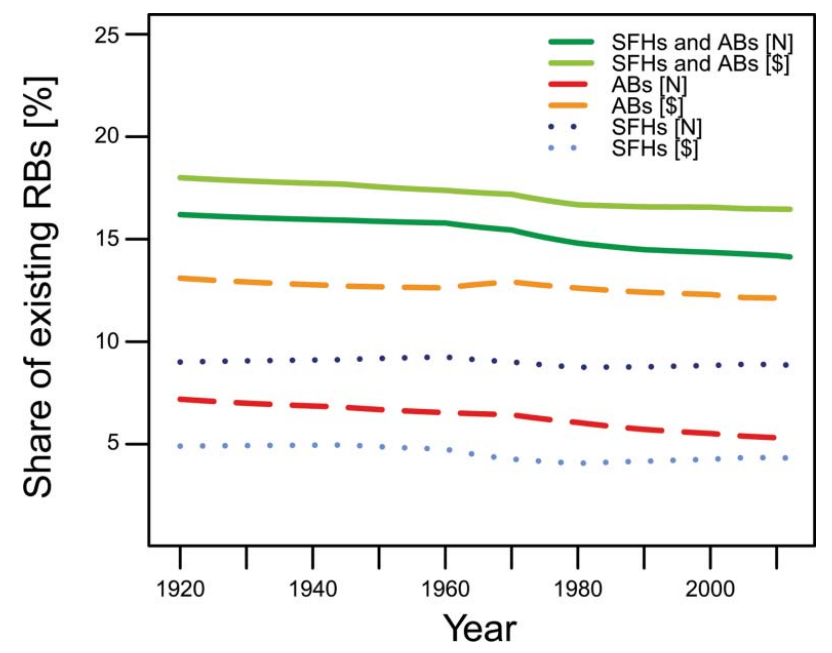

Figure 4. Share of exposed single-family houses and apartment buildings in relation to the total number of residential buildings. SFH = single-family house; $\mathrm{AB}=$ apartment building; $\mathrm{RB}=$ residential building. (Color figure available online.) considered, the share of RBs (number and value) slightly decreased from 1919 to 2012 (Figure 4), with a higher rate of decrease during the 1970s. If values and numbers are compared, the exposed $\mathrm{SFH}$ and ABs were becoming more expensive since the 1970s.

\section{Analysis of Policy Response in Natural Hazard Management}

Strategies to prevent or to reduce the effects of natural hazards in settlement areas can be traced back to medieval times; official authorities were only founded in 1876 (Switzerland) and 1884 (Austria) as a result of legal regulation (Schweizerische Eidgenossenschaft 1876; Österreichisch-Ungarische Monarchie 1884). Since then, efforts to minimize detrimental impacts to civilians and society have been centered on silvicultural measures to prevent erosion and the introduction of engineering structures within the catchment, along channel systems, and in deposition areas. Starting in the 1950s, conventional mitigation concepts, which were aimed at decreasing both the magnitude and frequency of events, were increasingly complemented with technical mitigation measures. The amendment of respective legal regulations marks a turning point in responsibility sharing. Changes were observed in the following examples: the Hydraulic Engineering Assistance Act (Republik Österreich 1848), the Water Act (Republik Österreich 1959), the Disaster Act (Republik Osterreich 1966), and the Forest Act (Republik Österreich 1975) in Austria and the Water Act and the Forest Act in Switzerland (Schweizerische Eidgenossenschaft 1991a, 1991b). As a result of these regulations, which were supplemented by multiple 
federal directives, protection against natural hazards became a governmental duty. Starting in the 1970s, with the Directive on Hazard Mapping in Austria (Republik Österreich 1976) and the National Spatial Planning Act in Switzerland (Schweizerische Eidgenossenschaft 1979), the use of nonstructural measures for natural hazard protection was implemented. As a result, spatial planning methods such as hazard maps aimed at reducing development activities in hazard-prone areas were introduced (Holub and Fuchs 2009). Multiple directives, such as the Directive on the Assessment of Flood Hazards in Spatial Planning (Bundesamt für Wasserwirtschaft, Bundesamt für Raumplanung, and Bundesamt für Umwelt, Wald und Landschaft 1997) in Switzerland and the Disaster Management Act (Republik Österreich 1996) in Austria supplemented these national laws, and further federal regulations from both countries were set into motion (Kanonier 2006). The European Union Floods Directive (Commission of the European Communities 2007) finally provided the basis for a risk-based management of flood hazards in European countries. In summary, we identified four key periods of natural hazard management in the European Alps, which are attributed to different hazard paradigms:

- In the 1870 s and 1880 s, a governmental system for natural hazard protection was introduced. The initial legal regulations that were focused on natural hazard management shifted to watershed management, forest-biological, soil bio-engineering measures, and technical measures (construction material: timber and stone masonry) for the first time.

- In the 1950s and 1960s, a shift toward engineering systems was observed. In the European Alps, the mitigation of mountain hazards was predicated on the implementation of structural engineering measures. These targeted the minimization of both the magnitude and frequency of events, which were increasingly complemented by more sophisticated technical mitigation measures.

- In the 1970s and 1980s, the system evolved to include a broader discussion on natural hazard management based on respective national laws. These laws served as responses to various natural hazard events. As a result, nonstructural measures supplemented engineering solutions. In particular, land use planning was introduced. Institutions and policymakers relied on a combination of structural and nonstructural measures to reduce the negative impact of future events.

- Finally, the risk-based approach was introduced in the 1990s. The shift from hazard to risk required a completely different approach to effectively address outstanding management issues. Here, the concept of risk is defined as a function of hazard and consequences. Comprehensive experiences have been documented about the application of the risk concept to mountain hazard management, especially in Switzerland. The risk-based approach was focused on encouraging a discourse on risk within respective societies. By considering different scenarios (including the aspect of residual hazard), a greater focus is placed on stakeholder engagement and bottomup initiatives, and the implementation of catchment-wide management concepts was observed.

\section{Discussion and Conclusion}

The aforementioned results clearly showed that effective exposure reduction has yet to be achieved. In fact, the evolution of new policy instruments in flood risk management has largely been unable to reduce increases in exposure for both countries. We observed that the new flood risk management strategies allowed continuous developments in floodplain areas. In particular, the expectation that engineered measures would protect floodplains had encouraged development instead. This resulted in increases in potential losses (White, Kates, and Burton 2001). In response, the public administration in Austria and Switzerland generated a situation of moral hazard within society (Tarlock 2012), because new buildings in hazard areas were secured by innovative defense strategies. For example, the Austrian housing subsidy system, which changed in 1958, led to an increase in public subsidies that are available for private house owners. As such, the total number of new RBs increased to $1,296,101$ between 1960 and 2012, compared to the 375,412 new RBs between 1919 and 1960. Consequently, the availability of housing subsidies contributed to the development of SFHs; during the period of investigation, more than 115,687 were constructed in hazardprone areas with financial support from the government. This effect is referred to as perverse subsidies (van Beers and Van Den Bergh 2001). Furthermore, the Austria Superior Administrative Court decided 
against enforcing the production of hazard maps as a part of statutory regulation for spatial planning; instead they are only judged as an expert report (Verwaltungsgerichtshof 1995).

Because an absolute decrease in exposed RBs would only be possible if the original buildings are removed from identified hazard zones, we computed the hypothetical development of the buildings based on a scenario where a construction ban is enforced in endangered areas. To demonstrate the effectiveness of such a ban, associated legal regulations were assumed to be effective in the 1970s and the 1990s, respectively. If we hypothetically assume that starting in 1976, which coincides with the amendment to the Directive on Hazard Mapping in Austria, further development in hazard-prone areas would have been stopped, a total of 162,907 buildings would not have been constructed in exposed areas. This number equates to -32 percent of exposure. Similarly, after 1991, which coincides with the amendment of the Water Act and the Forest Act in Switzerland, a total of 102,935 buildings would not have been constructed in hazard-prone zones. This is equivalent to -20 percent exposure. Consideration for these scenarios also demonstrates the importance of time when investigating the effectiveness of nonstructural measures. For instance, it recommends that land use planning policies should be consistently implemented over longer temporal horizons.

The policy system encourages private homeownership, despite associated increases in vulnerability. Another driver that contributed to increased exposure was the interpretation of land use management regulations at local levels. In some of the regions belonging to the fourth quartile of exposure (Figure 1), the regional land use management act allowed the construction of houses outside of defined building zones in land use plans; consequently, around 7,000 out of a total of 12,000 new residential buildings were constructed due to this exemption. Furthermore, governmental organizations interpreted how land was protected by engineering structures differently. In Salzburg, for example, new buildings and settlements were built to create dense urban areas, resulting in an increase in exposure in high-risk areas. Moreover, the public administration seemed to have ignored the problem of exposure, as natural hazard management had little or no impact on the design of local land use plans and strategies. This is explained by the fact that economic growth within administrative boundaries is regularly prioritized above ecological concerns or protection against hazards (Thaler 2014; Thaler, Priest, and Fuchs 2016).

The observations show that the exposure of RBs has considerably increased over the last ninety years. This rise has been observed despite the introduction of natural hazard management strategies in the European Alps. This development was heavily influenced by the occurrence of disasters, which led to an increased gravitation toward the dependency on technical mitigation measures but did not prevent further unsuitable land use developments. Moreover, acknowledging the levee effect, natural hazard management encouraged further development of hazardprone areas with the consequence of an increase of exposure dynamics. As such, both systems (exposure dynamics and management paradigms) are profoundly interrelated, where increases in exposure necessitate further mitigation measures. These measures evolve from purely engineered solutions toward risk-based planning approaches. The implementation of key strategies in isolation, however, does not completely eliminate potential losses due to damages over time. Instead, a lock-in situation results, where the reliance on technical mitigation measures that dominate current risk management approaches continues to be more prominent than the perceived impact of land use planning.

To break away from the way exposure has been addressed to date, there is a need to set incentives to ensure responsible natural hazard management. This requires rigorous enforcement of land use planning legislation (e.g., reconsideration of perverse subsidies from a political perspective), which would foster the popularization of alternative hazard mitigation measures and promote the implementation of coherent policies. It would also support the development of further incentives to minimize risk. Natural hazard risk management will only be successful if the further development of construction in hazard-prone areas is restricted.

The aforementioned management approaches ensure the availability and accessibility of knowledge on natural hazard risk and how this can be effectively applied to a range of societal conditions. The result would be a paradigm shift in natural hazards management, which would result in decreased vulnerability and increased resilience for the affected population.

\section{Funding}

This study received funding from the Austrian Science Fund (FWF): P27400. 


\section{Supplemental Material}

Supplemental data for this article can be accessed on the publisher's Web site at http://dx.doi.org/ 10.1080/24694452.2016.1235494.

\section{ORCID}

Sven Fuchs (D) http://orcid.org/0000-0002-06442876

Veronika Röthlisberger (D) http://orcid.org/00000003-1911-6268

Thomas Thaler (iD) http://orcid.org/0000-0003-3869. 3722

Andreas Zischg (1D) http://orcid.org/0000-0002-47497670

Margreth Keiler (D) http://orcid.org/0000-00019168-023X

\section{References}

Andres, N., A. Badoux, and C. Hegg. 2015. Unwetterschäden in der Schweiz im Jahre 2014 [Swiss hazard losses in 2014]. Wasser, Energie, Luft 107 (1): 47-54.

Bard, A., B. Renard, and M. Lang. 2012. Floods in the alpine areas of Europe. In Changes in flood risk in Europe, ed. Z. Kundzewicz, 362-71. Boca Raton, FL: CRC.

Barredo, J. 2009. Normalised flood losses in Europe: 19702006. Natural Hazards and Earth System Sciences 9 (1): 91-104.

Bundesamt für Statistik. 2012. Eidgenössisches Gebäude-und Wohnungsregister, Merkmalskatalog [Swiss federal building register, catalogue of characteristics]. Neuchâtel, Switzerland: Bundesamt für Statistik.

Bundesamt für Wasserwirtschaft, Bundesamt für Raumplanung, and Bundesamt für Umwelt, Wald und Landschaft. 1997. Berücksichtigung der Hochwassergefahren bei raumwirksamen Tätigkeiten [Acknowledging flood hazards in spatial planning]. Biel und Bern, Switzerland: BWW, BRP, BUWAL.

Commission of the European Communities. 2007. Directive 2007/60/EC of the European Parliament and of the Council of 23 October 2007 on the assessment and management of flood risks. Official Journal of the European Union 288:27-34.

Fuchs, S. 2009. Susceptibility versus resilience to mountain hazards in Austria-Paradigms of vulnerability revisited. Natural Hazards and Earth System Sciences 9 (2): 337-52.

Fuchs, S., M. Keiler, S. A. Sokratov, and A. Shnyparkov. 2013. Spatiotemporal dynamics: The need for an innovative approach in mountain hazard risk management. Natural Hazards 68 (3): 1217-41.

Fuchs, S., M. Keiler, and A. Zischg. 2015. A spatiotemporal multi-hazard exposure assessment based on property data. Natural Hazards and Earth System Sciences 15 (9): $2127-42$.
Gual, M. A., and R. B. Norgaard. 2010. Bridging ecological and social systems coevolution: A review and proposal. Ecological Economics 69 (4): 707-17.

Hodgson, G. 2006. What are institutions? Journal of Economic Issues 40 (1): 1-25.

Holub, M., and S. Fuchs. 2009. Mitigating mountain hazards in Austria-Legislation, risk transfer, and awareness building. Natural Hazards and Earth System Sciences 9 (2): 523-37.

Jongman, B., E. E. Koks, T. G. Husby, and P. J. Ward. 2014. Increasing flood exposure in the Netherlands: Implications for risk financing. Natural Hazards and Earth System Sciences 14 (5): 1245-55.

Kallis, G. 2007. When is it coevolution? Ecological Economics 62 (1): 1-6.

Kanonier, A. 2006. Raumplanungsrechtliche Regelungen als Teil des Naturgefahrenmanagements [Land use planning regulations as part of natural hazard management]. In Recht im Naturgefahrenmanagement, ed. S. Fuchs, L. Khakzadeh, and K. Weber, 123-53. Innsbruck, Austria: Studienverlag.

Keiler, M. 2004. Development of the damage potential resulting from avalanche risk in the period 1950-2000, case study Galtür. Natural Hazards and Earth System Sciences 4 (2): 249-256.

Keiler, M., S. Fuchs, A. Zischg, and J. Stötter. 2004. The adaptation of technical risk analysis on natural hazards on a regional scale. Zeitschrift für Geomorphologie 135 (Suppl.): 95-110.

Keiler, M., J. Knight, and S. Harrison. 2010. Climate change and geomorphological hazards in the eastern European Alps. Philosophical Transactions of the Royal Society of London A 368: 2461-79.

Keiler, M., R. Sailer, P. Jörg, C. Weber, S. Fuchs, A. Zischg, and S. Sauermoser. 2006. Avalanche risk assessment-A multi-temporal approach, results from Galtür, Austria. Natural Hazards and Earth System Sciences 6 (4): 637-51.

Kienholz, H., B. Krummenacher, A. Kipfer, and S. Perret. 2004. Aspects of integral risk management in practice-Considerations with respect to mountain hazards in Switzerland. Österreichische Wasser-und Abfallwirtschaft 56 (3-4): 43-50.

Kubal, C., D. Haase, V. Meyer, and S. Scheuer. 2009. Integrated urban flood risk assessment-Adapting a multicriteria approach originally developed for a river basin to a city. Natural Hazards and Earth System Sciences 9 (6): 1881-95.

Loucks, D., and J. Stedinger. 2007. Thoughts on the economics of floodplain development in the U.S. In Extreme hydrological events: New concepts for security, ed. O. Vasiliev, P. van Gelder, E. Plate, and M. Bolgov, 319. Dordrecht, The Netherlands: Springer.

Mudelsee, M., M. Börngen, G. Tetzlaff, and U. Grünewald. 2003. No upward trends in the occurrence of extreme floods in central Europe. Nature 425 (6954): 166-69.

Munich Re. 2016. Topics geo: Natural catastrophes 2015. Munich, Germany: Munich Re.

Nordregio. 2004. Mountain areas in Europe: Analysis of mountain areas in EU member states, acceding and other European countries. Final report, Nordregio, Stockholm, Sweden. 
Österreichisch-Ungarische Monarchie. 1884. Gesetz, betreffend Vorkehrungen zur unschädlichen Ableitung von Gebirgswässern [Law related to the nonhazardous discharge of mountain waters]. Wien, Austria: Kaiserlichkönigliche Hof-und Staatsdruckerei.

Papathoma-Köhle, M., M. Kappes, M. Keiler, and T. Glade. 2011. Physical vulnerability assessment for alpine hazards: State of the art and future needs. Natural Hazards 58 (2): 645-80.

Papathoma-Köhle, M., A. Zischg, S. Fuchs, T. Glade, and M. Keiler. 2015. Loss estimation for landslides in mountain areas-An integrated toolbox for vulnerability assessment and damage documentation. Environmental Modelling and Software 63:156-69.

Remo, J. W. F., M. Carlson, and N. Pinter. 2012. Hydraulic and flood-loss modeling of levee, floodplain, and river management strategies, Middle Mississippi River, USA. Natural Hazards 61 (2): 551-75.

Republik Österreich. 1948. Wasserbautenförderungsgesetz [Federal Hydraulic Engineering Development Act]. BGBl 34/1948.

. 1959. Wasserrechtsgesetz [Federal Water Act]. BGBl 215/1959.

—. 1966. Bundesgesetz vom 9. September 1966 über den Katastrophenfonds [Federal Act of 9 September 1966 on the Disaster Fund]. BGBl. Nr. 207/1966.

- 1975. Forstgesetz [Federal Forest Act]. BGBl 440/ 1975.

. 1976. Verordnung des Bundesministers für Landund Forstwirtschaft vom 30. Juli 1976 über die Gefahrenzonenpläne [Decree of the Federal Minister for Agriculture and Forestry of 30 July 1976 related to hazard mapping]. BGBl 436/1976.

- 1966. Bundesgesetz vom 9. September 1966 über den Katastrophenfonds [Federal Act of 9 September 1966 on the Disaster Fund]. BGBl. Nr. 207/1966.

Schweizerische Eidgenossenschaft. 1876. Bundesgesetz betreffend die eidgenössische Oberaufsicht über die Forstpolizei [Federal law related to the confederate supervision of the Swiss Forest Police]. BS 9521.

. 1979. Bundesgesetz über die Raumplanung [Federal law on spatial planning]. SR 700.

_. 1991a. Bundesgesetz über den Wald [Federal Forest Act]. SR 921.0.

. 1991b. Bundesgesetz über den Wasserbau [Federal Hydrography Act]. SR 721.100.

Statistik Austria. 2004. Gebäude-und Wohnungszählung 2001-Hauptergebnisse Österreich [Census of buildings and flats 2001-Main results for Austria]. Wien, Austria: Statistik Austria.

—. 2012. Adress-GWR Online Handbuch, Teil C, Anhang 2: Merkmalskatalog. Wien, Austria: Statistik Austria.

Swiss Re. 2016. Natural catastrophes and man-made disasters in 2015. Zurich: Swiss Re.

Tappeiner, U., A. Borsdorf, and E. Tasser. 2008. Alpenatlas [Atlas of the Alps]. Heidelberg, Germany: Springer.

Tarlock, A. D. 2012. United States flood control policy: The incomplete transition from the illusion of total protection to risk management. Duke Environmental Law 83 Policy Forum 23:151-83.

Thaler, T. 2014. Developing partnership approaches for flood risk management: Implementation of inter-local co-operations in Austria. Water International 39 (7): 1018-29.

Thaler, T., S. Priest, and S. Fuchs. 2016. Evolving interregional co-operation in flood risk management: Distances and types of partnership approaches in Austria. Regional Environmental Change 16 (3): 841-53.

Theiling, C. H., and J. T. Burant. 2013. Flood inundation mapping for integrated floodplain management: Upper Mississippi River system River Research and Applications 29:961-78.

Totschnig, R., and S. Fuchs. 2013. Mountain torrents: Quantifying vulnerability and assessing uncertainties. Engineering Geology 155:31-44.

van Beers, C., and J. C. J. M. Van Den Bergh. 2001. Perseverance of perverse subsidies and their impact on trade and environment. Ecological Economics 36 (3): 475-86.

van den Bergh, J. C. J. M., and S. Stagl. 2003. Coevolution of economic behaviour and institutions: Towards a theory of institutional change. Journal of Evolutionary Economics 13 (3): 289-317.

Verwaltungsgerichtshof. 1995. Erkenntnis 91/10/0090 [Decision 91/10/0090] (27.03.1995) https://www. ris.bka.gv.at/Dokumente/Vwgh/JWT_1991100090_ $19950327 \times 00 / J W T \_1991100090 \_19950327 \times 00 . p d \overline{d f}$ (last accessed 1 December 2015).

White, G., R. Kates, and I. Burton. 2001. Knowing better and losing even more: The use of knowledge in hazards management. Environmental Hazards 3 (3-4): 81-92.

Wiering, M., and I. Immink. 2006. When water management meets spatial planning: A policy-arrangements perspective. Environment and Planning C: Government and Policy 24 (3): 423-38.

Zimmermann, M., and M. Keiler. 2015. International frameworks for disaster risk reduction: Useful guidance for sustainable mountain development? Mountain Research and Development 35 (2): 195-202.

SVEN FUCHS is Senior Scientist in the Institute of Mountain Risk Engineering at the University of Natural Resources and Life Sciences, Vienna 1190, Austria. E-mail: sven.fuchs@boku.ac.at. His research interests include mountain hazard risk management, the study of coupled human-environment systems, and vulnerability assessment for natural hazards.

VERONIKA RÖTHLISBERGER is a PhD candidate in the Institute of Geography at the University of Bern, Bern 3012, Switzerland. E-mail: veronika.roethlisberger@giub.unibe.ch. She is also member of the Mobiliar Lab for Natural Risks at the Oeschger Centre for Climate Change Research at the University of Bern. Her research interests include risk assessment and management of floods, spatial statistics, and the analysis of economic data in the context of flood risk.

THOMAS THALER is a Research Fellow in the Institute of Mountain Risk Engineering at the University of Natural Resources and Life Sciences, Vienna 1190, Austria. E-mail: thomas.thaler@boku.ac.at. His research interests include policy issues in mountain hazards, focusing on national risk management and related policy strategies in different European countries. 
ANDREAS ZISCHG is a Scientist in the Institute of Geography at the University of Bern, Bern 3012, Switzerland, and he is also affiliated with the Mobiliar Lab for Natural Risks of the Oeschger Centre for Climate Change Research at the University of Bern. E-mail: andreas.zischg@giub.unibe.ch. His research interests include flood risk modeling.
MARGRETH KEILER is Associate Professor in the Institute of Geography at the University of Bern, Bern 3012, Switzerland. E-mail: margreth.keiler@giub.unibe.ch. Her research interests include hazard assessment of floods, landslides and multihazards, vulnerability, risk and resilience in the context of natural disasters, risk evolution, coupled human-landscape systems, and complex system research. 